\title{
Невымышленная проза Арктики (на материале книги Н. Курилова «Хай!»)
}

\author{
Потапова Е.А., магистрант, \\ Северо-Восточный федеральный университет, \\ 2. Якутск \\ E-mail: zheeenya94@mail.ru
}

Научный руководитель: о.ф.н., профессор Хазанкович Ю.Г.

В статье представлен опыт типологического исследования «невымышленной прозы» в литературах малочисленных народов Севера. Объектом исследования являются путевые заметки юкагирского писателя Николая Курилова «Хай!». Факты, детали, даты, последовательность событий, географические названия реальны и «поддержаны» дневниковой формой повествования.

Что такое документальная литература? В русском литературоведении при изучении и выявлении специфики документальной литературы имя Елены Местергази занимает одну из главных мест. В своей экспериментальной энциклопедии «Литература нон-фикшн/non-fiction» автор дает следующее определение термину: «документальная литература (документалистика) - прозаическое произведение, в которых художественная реальность создается на основе документальных фактов» [2, 2007: 8].

Для документальной, т.е. «невымышленной» литературы характерно построение сюжетной линии исключительно на реальных событиях, с редкими вкраплениями художественного вымысла. Она основана на воспоминаниях очевидцев, документах. Также могут использоваться воспоминания самого автора. Своей документальностью воссоздает яркие, живые картины событий, психологические облики людей.

К жанрам документальной литературы относят письма, мемуары (записки современников, повествующие о событиях, в которых автор мемуаров принимал участие или которые известны ему от очевидцев), записки, записные книжки писателей, описанию путешествий, биографию, автобиографию, иногда очерк и эссе, а также дневник.

Цель нашего исследования - выявить традиции и поэтику «невымышленной прозы» Н. Курилова, а также представить образовательно-просветительский проект для школьников «Дневник путешественника», разработанный на основе книги «Хай!» Н. Курилова.

Задачи: показать природу документальной, «невымышленной» литературы и определить ее место в юкагирской литературе; разработать дневник путешественника на основе путевых заметок юкагирского писателя Н. Курилова «Хай!» в качестве образовательно-просветительского проекта, предназначенного для школьников.

«Невымышленная литература», признаки которой даны в энциклопедии Е. Местергази «Литература нон-фикшн/non-fiction», у писателей малочисленных народов Севера прослеживается давно. На протяжении всего существования художественной словесности автобиографическая и «невымышленная» проза у северян развивалась параллельно. Это очерк зачинателя юкагирской литературы Тэки Одулока «На Крайнем Севере» (1927), Н. Тарабукина «Мое детство» (1936), А. Амамич «Не провожайте с тоской улетающих птиц» (1977), автобиографическая «повесть» ненецкой писательницы Нины Ядне «Я родом из тундры» (1995), М. Федотовой «Шалунья 
Нулгынэт» (1999), книга эпистолярного наследия долганской поэтессы Огдо Аксеновой «Я пишу Вам больше от радости» (2001), воспоминания юкагира Н. Курилова «Хай!» и др. Появление таких произведений было определено самой задачей, стоявшей перед писателями, - осмысление исторических перемен посредством рассказа о себе и собственной культуре [4, 2016: 184].

В данной работе особое внимание, как к «невымышленной литературе» уделяется воспоминаниям Н. Курилова «Хай!» - это познавательные заметки о путешествии автора к североамериканским индейцам в 1994-1995 гг. в основу которого положен дневник самого автора, наполненный красочными фотографиями и рисунками. Автор рассказывает нам о своих впечатлениях и воспоминаниях о путешествии, передает ту атмосферу и обстоятельства, которые он повстречал.

Книга Николая Курилова «Хай!» - это путевые заметки. Следовательно, можно отметить, что жанр дневника и путешествия тесно связаны и дополняют друг друга. Автор сохраняет условность жанра путешествия - присваивает к каждой главе характерные содержанию названия, по которым читатель буквально переносится в те события, которые описывает автор. Здесь также писатель озабочен, условно говоря, пейзажами человеческой души - анализом духовного климата личности. Главные происшествия, описываемые Н. Куриловым, разыгрываются в встречах, выставках, знакомствах - то печалят, то радуют душу рассказчика. Автор в образе путешественника чуток ко всем впечатлениям бытия и склонен к самоанализу. Именно углубленное изображение внутреннего мира героев позволяет говорить о близости жанра дневника и путешествия.

Таким образом, жанр путешествия «вносит свой вклад» в развитие жанра дневника, а именно дает возможность не только изображать внутренний мир героев, но и анализировать возникшие впечатления в связи с переменой мест и обстановки.

Книга состоит из 25 глав-заметок. Фактологическая детализация, простой язык, реалистичность, историзм, единение драматизма и обыденности - все это присущи путевым заметкам Курилова. То, как он обращается к читателю, как он пишет об индейцах, которые живут в Америке, о праздниках, о традициях и обычаях, прослеживается оживленность.

Острая тематика и проблемы общечеловеческого характера интересны читателям, они значительно расширяют их литературный и историко-культурный кругозор, способствуют развитию мышления и эстетического вкуса. В заметках автор пишет, что их имена малоизвестны для местных любителей искусства коренных народов; сама техника исполнения работ неизвестны; и, главное - нет своего имиджа. «Имиджу помогает такое немаловажное дополнение к имени и фамилии, как национальность» [1, 1997: 39]. Если у нас, например, в картине пишут: такая-то работа и автор, то у индейцев же, после имени и фамилии, пишут и национальность. Автор пишет об этом совершенно свободно. Это та свобода самовыражения, которая несет полноту пережитых мыслей и оттенков чувства. Это не только материал о путешествии автора, это и освещение исторических событий, очевидцем которого он являлся.

В юкагирской литературе, кроме произведения Н. Курилова «Хай!», к «невымышленной прозе» можно отнести очерки Тэки Одулока «На Крайнем Севере», написанные в 1933 г. по материалам экспедиции 1927 г. В произведениях обоих писателей юкагирской литературы встречаются черты документальной, «невымышленной» литературы: сюжетные линии произведений построены исключительно на реальных событиях; основаны на воспоминаниях очевидцев, 
документах и, безусловно, самих авторов; характерны также установка на объективность, документальную точность, автобиографичность и отсутствие художественности [4, 2016: 185].

Каждое произведение носит свой характер, что делает его отличительным от других произведений. В очерках Т. Одулока «На Крайнем Севере» автор не только описывает жизнь народов Севера, их быт, нравы и хозяйство, которые так знакомы писателю, но, как истинный сын своего народа, поднимает проблему их приобщения к новой цивилизации. «Невымышленность» этого произведения создает множество вопросов, среди которых главным можно считать вопросы «А как сейчас, в XXI веке, живут на Крайнем Севере?» и «Есть ли сейчас жизнь на Крайнем Севере?». Атмосфера произведения Т. Одулока пронизана надеждой и верой в светлое, хорошее будущее, что представители народов кочевья ни на один день не унывают, они - дети тундры, а тундра - это их жизнь.

В путевых заметках Н. Курилова ощущается авторское присутствие по его идиостилю, манере донести мысль. Также передаются мельчайшими интонациями образы героев произведения, так как все они и описываемые события взяты из реальной жизни, сохранены подлинные названия и имена. Вымысел отсутствует.

Острая тематика и проблемы общечеловеческого характера интересны читателям, они значительно расширяют их литературный и историко-культурный кругозор, способствуют развитию мышления и эстетического вкуса. Чтобы добиться этих результатов, начиная со школы, надо приобщить интерес к документальной литературе. Чтением документальной литературы можно заниматься во внеклассных занятиях или в виде дополнительного чтения на дом. В данном случае объектом чтения, через которое читатели, т.е. ученики могут расширить кругозор, интерес и мышление, служит книга Н. Курилова «Хай!». Прочитав и вникнув в суть произведения, учащиеся узнают, что такое «невымышленная литература». На основании этого был разработан «Дневник путешественника», предназначенный для школьников-путешественников, с помощью которого мы развиваем способности воспринимать, понимать и интерпретировать произведение, а также они учатся создавать свои собственные тексты, аналогичной путевым заметкам Н. Курилова «Хай!».

Исследование дневника путешественника (путевых заметок), которые легли на основу создания книги «Хай!», дало понять нам, что и в юкагирской прозе, и в литературе малочисленных народов Севера в том числе, как и в русской и зарубежной литературах, есть произведения, которые можно отнести к документальной «невымышленной» прозе. На основе таких произведений можно определить достоверность/недостоверность фактов. Проведенная нами работа убедила нас, что повесть «Хай!» относится именно к жанру дневника «невымышленной литературы», в котором дается правдивое описание событий и лиц, которые сам автор испытал и повстречал, и которые написаны без лишних красок. Это рассказ рассказа о своей жизни во время путешествия с запечатлением мыслей и чувств. Благодаря этому повесть «Хай!» обретает качество подлинного свидетельства, в основе которого достоверный факт и настоящая реальность, подтверждая, что «ничего не может быть прекраснее того, что в самом деле существует в действительности. Следовательно, прекрасное есть жизнь» [6, 2016: 189]. 


\section{Список литературы:}

1. Курилов Н.Н. Хай! Путевые заметки /Н.Н. Курилов. - Якутск, Нац. кн. изд. «Бичик» 1997 - 72 с.

2. Местергази Е.Г. Литература нон-фикшн/non-fiction / Е.Г. Местергази. - М.: Совпадение, 2007. - 325 с.

3. Огрызко В.В. Юкагирская литература: Сборник / В.В. Огрызко. - М.: Литературная Россия, 2006. - 376 с.

4. Хазанкович Ю.Г. «Кочевье длиною в жизнь» Андрея Кривошапкина: nonfiction в эвенской литературе /Ю.Г. Хазанкович // Вестник Бурятского государственного университета. - 2016. - №2.

\section{Этимологический анализ имен собственных героического эпоса-олонхо (на примере олонхо И.М. Давыдова «Тойон Ньургун» и Н.Ф. Попова «Тойон Ньургун Боотур»)}

Рахлеева В.Л., студентка, Северо-Восточный федеральный университет, 2. Якутск

E-mail: raxleeva98@mail.ru

\section{Научный руководитель: к.ф.н., доцент Собакина И.В.}

Олонхо - древнейшее эпическое искусство народа саха. Занимает центральное место в системе якутского фольклора. Термин «олонхо» обозначает как эпическую традицию в целом, так и название отдельных сказаний. В 2005 году ЮНЕСКО объявило олонхо одним из «шедевров устного и нематериального наследия человечества».

Этимологический (от греч. etymon - истина, основное значение слова + logos понятие, учение) анализ - выяснение ранее существовавшего морфологического строения слова, его прошлых словообразовательных связей, определение источника и времени появления слова, установление способа его образования от соответствующей производящей основы.

В школьные годы, в начальных классах я обучалась с правнуками Иллариона Михайловича Давыдова и они каждый день рассказывали мне про своего дедушку и о том, как он красиво передает образы.

Олонхо Иллариона Михайловича Давыдова "Тойон Ньургун" было записано в Модьукайском наслеге Реасом Алексеевичем Кулаковским, так как И.М.Давыдов был безграмотным, рано потерял зрение. Запись датирована 1940-м годом, имеет 482 листа и 10317 стихотворных строк и считается большим эпическим произведением. В наше время данное произведение было напечатано в 2003 году, в республиканской серии книг "Богатыри Саха".

В предлагаемой работе наряду с олонхо Иллариона Михайловича Давыдова "Тойон Ньургун" проводится сравнительный анализ с олонхо Николая Филипповича Попова "Тойон Ньургун". Это олонхо было написано в 1895 году и имеет более 4000 стихотворных строк, переиздано Кузьминой Айталиной Ахметовной, научным 